\title{
Development of Hierarchical Checking Tables for Safety Management of Apartment Gang-form Works
}

\author{
Kang, Jung $-\mathrm{Woo}^{1}$ Cho, Dong $-\mathrm{Hyun}^{2} \quad$ Koo, Kyo-Jin ${ }^{2 *}$ \\ GS Engineering \& Construction Corp, Joong-Gu, Seoul, 100-722, Korea ${ }^{1}$ \\ Department of Architectural Engineering, The University of Seoul, Dongdaemun-Gu, Seoul, 130-743, Korea ${ }^{2}$
}

\section{Abstract}

The gang-form widely used in apartment construction sites has advantages compared to scaffolding in preventing falling accidents. One problem, however, is that safety accidents associated with gang-form works repeatedly occur due to worker carelessness. In this study, hierarchical checking tables are provided to support safety management activities for the gang-form works at the sites. Through a survey of experts and analyses of case studies of construction accidents, 137 safety check items are classified by participant type based on a hierarchical safety check scheme. The applicability and effectiveness of the hierarchical checking tables was evaluated through interviews with experts. It was found that the hierarchical checking tables enabled each gang-form related participant to check his own safety management items, and provided a level-wise structure to site safety management systems.

Keywords : apartment, gang-form, safety management, hierarchical checking tables

\section{Introduction}

\subsection{Research objective}

As the limited amount of land available and the advancement in construction methods led to the construction of high-rises and large scale apartment buildings, large formwork systems such as slip-form or gang-form are generally used at construction sites. In particular, gang- forms are in wide use as a form at most apartment construction sites[1]. The gang-form is a kind of modular formwork system, the installation of which is standardized, for which no skilled work is needed. As the form can be used repeatedly, it promotes cost efficiency [2]. It has two advantages: (1) good durability due to its material characteristics and (2) increased safety in the work environment by using

Received : March 18, 2013

Revision received : October 4, 2013

Accepted : October 18, 2013

* Corresponding author : Koo, Kyo-Jin

[Tel : 82-2-6490-2760, E-mail : kook@uos.ac.kr]

(c)2014 The Korea Institute of Building Construction, All rights reserved. safety equipment such as corner-plate, safety railing and so on. Despite these advantages, of the serious safety disasters occurring on construction sites between 2004 and 2010, gang - form related accidents accounted for $30 \% 1$. For this reason, there is an urgent need to clarify the safety risk factors and appropriate safety management activities. In particular, formwork systems are excluded from the "Dangerous Machinery" category under the Occupational Safety and Health Act, and the lack of design or production standards for formwork systems make the safety risk high. Public and private safety guidelines were developed and utilized to overcome this limitation, however, these are limited in that the management and checking participants are not specified, and there is a huge number of inspection items, leading to a dependency on the experience or knowledge of safety managers.

This study proposes hierarchical checking tables for the efficient safety management of apartment gangform works. With checking tables, participants can perform systematic inspection activities based on a

1) Korea Occupational Safety \& Health Agency, Cases and Countermeasures of Severe Construction Disaster, 2004-2010 
clear division of roles, without any omissions. In addition, the field safety managers can integrate and manage major management items by construction phase and participant, and active and preventive safety management activities can be performed on an ongoing basis.

\subsection{Research scope and methodology}

The safety management of this study is applied only to apartment houses classified by Article 3 Clause 4 of the Enforcement Ordinance of the Building Act. The research scope of gang-forms is both for the external wall form and for the scaffolding, and the range of the gang-form works include on-site assembly and installation, salvage and installation stage. In addition, the subjects of safety management at construction sites are limited to workers, management supervisors, and safety managers.

The research process of this study is as follows: First, a review of the literature was performed to investigate gang-form works and construction safety management. Second, the current status of gang-form safety management is analyzed through a case study of construction disasters and a $1^{\text {st }}$ questionnaire survey of gang-form works experts to derive problems and identify improvements. Third, hierarchical checking tables for safety management was proposed based on the analysis of safety guidelines by identifying common safety rules and safety check items, and the $2^{\text {nd }}$ questionnaire survey with practitioners. Fourth, the field applicability of the checking tables for safety management was validated through interviews with practitioners,

\section{Literature review}

\subsection{Gang-form works}

Formwork, which usually accounts for 30\%-40\% of the structural construction cost, or about 10\% of the total construction cost, is one of the largest single processes, it has a determining impact on the subsequent work[3,4]. System forms, which offer the advantages of reducing construction duration and improving work efficiency and quality, are frequently being used in large buildings rather than using scaffolding. The types of system form include gang-form, table form, tunnel form, traveling form, and slip form [5].

The safety equipment for gang-form is comprised of work scaffold, safety ladder, cage, vertical protective net, and lifting hook, and the gang-form work proceeds in the order of on-site assembly, installation, lifting and demolition(Figure1). In particular, the lifting and demolition work consists of 8 detailed work types, including the disassembly of anchor bolts and tie bolts.

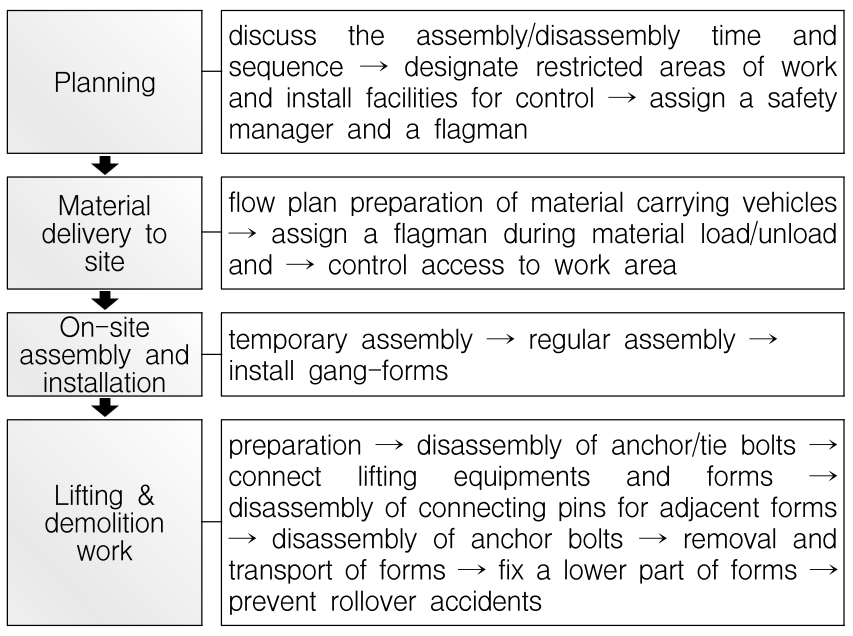

Figure 1. Gang-form works process

\subsection{Current state of disaster prevention in construction work}

The fatal accident rate and the death toll in construction field are the highest of all industrial fields, and similar accidents occur repeatedly[6,7]. Diverse efforts have been made in the public and private sector to prevent safety accidents and to establish effective safety management. The government enacted the Industrial Safety and Health Law and diverse safety guidelines for different types of construction projects to promote standardized safety management, and private general contractors have developed in-house guidelines and safety management systems.

The government legislated 'the Industrial Safety and Health Law' and established diverse safety guidelines for different types of construction projects to promote standardized safety management, and several private general contracting companies have developed in-house 
guidelines and safety management systems. Despite this national effort made to prevent construction disasters, a number of fatal accidents still occur in the construction field in Korea since a lack of safety consciousness among workers[7] and the inappropriateness of the safety management framework[8].

In most of the studies with regard to accident prevention in construction work, many efforts have been made to identify key factors causing accidents and to present apposite preventive measures in various types of facilities and work types. These can be subdivided into four major categories: (1) analysis of the key risk factors and preventive measures based on literature reviews and surveys [9,10], (2) improvement of the onsite safety management framework[8,11], (3) enrichment of the safety management method through objective evaluation criteria and/or tools, (4) and development of a safety management system using diverse information technologies[14,15].

Also, several studies have been undertaken with regard to the formwork: (1) safety management through the classification and quantification of risk factors[16], (2) secure safety by using the automated measuring system operated through wireless communications technology, including the Ubiquitous Sensor Network[17], (3) checklist- based safety management[18,19,20]. In particular, checklist- related studies have low applicability of the checklist to construction sites since the limitations shown in Table 1, and insufficiency efforts have been made to investigate the present status of utilization of checklists and to establish apposite checklist utilization plans.

Table 1. The limitations of checklist-related study in construction

\begin{tabular}{|c|c|}
\hline Author & limitations \\
\hline $\begin{array}{l}\text { Yang } \mathrm{YC} \text {, } \\
\text { Choi } \mathrm{H}, \\
\text { Kim Jj }\end{array}$ & $\begin{array}{l}\text { - Lack of field application based on computer-based } \\
\text { safety management method }\end{array}$ \\
\hline $\begin{array}{l}\text { Shim UJ, } \\
\text { Suh HS, } \\
\text { Ahn YS }\end{array}$ & $\begin{array}{l}\text { An exclusive checklist for reinforced concrete } \\
\text { construction }\end{array}$ \\
\hline $\begin{array}{l}\text { Kim JR, } \\
\text { Yoon SY, } \\
\text { Cho YJ. }\end{array}$ & $\begin{array}{l}\text { - Risk of cognitive dissonance based on recognizing } \\
\text { risk factors before and after work concurrently } \\
\text { - Difficulty of concurrent checking of multiple safety } \\
\text { check items }\end{array}$ \\
\hline $\begin{array}{l}\text { Common } \\
\text { items }\end{array}$ & $\begin{array}{l}\text { - Ambiguity of classification of safety-check activities } \\
\text { - An exclusive checklist for safety managers (not for } \\
\text { worker) } \\
\text { - Lack of priority of safety check items } \\
\text { - Lack of a crosschecking function by participants }\end{array}$ \\
\hline
\end{tabular}

Yang YC, Choi $\mathrm{H}$ and Kim JJ analyzed the current state of checklist use based on a case study of the site safety management of the top 30 General contractors companies in Korea. According to the result of the investigation, there are few companies using checklists at construction site, since the checklist is difficult to use for the reasons of 1) lack of inspection items for detailed work level and 2) need of accumulated experience and skills[18]. Shim UJ, Suh HS and Ahn YS presented a checklist for safety management of reinforced concrete work, but only concentrated on deriving items through an analysis of disaster factors[19]. Kim JR, Yoon SY and Cho YJ developed a card-type checklist for safety managers that was based on the probability of human error and the process order of a highway construction project. The work items to be checked are not classified by participant for on-site work, and thus are available only to safety managers[20].

Measures to prevent disasters have been presented through a wide range of studies, but little research has been done on support for complementary management activities of the safety inspection body at construction sites. Despite the diverse studies on preventing construction disasters, little effort has been made in support of complementary management activities of the safety inspection body at construction sites. Consequentially, there is a need to develop the preventive safety management activity supporting tools for the participants in the construction site.

\section{Current safety management of gang-form works}

To analyze the current state of safety management for gang-form work and present improvement directions, the key factors of each accident were classified using case studies of construction disasters in terms of the gang-form. Next, safety management criteria by construction stage were analyzed for the safety guidelines of public and private gang-form work. Along with the literature analysis, a questionnaire survey was performed with the on-site safety managers to identify the occurrences of fatal accidents in construction practice 
and the current state of the utilization of safety guidelines. Finally, based on the analysis results, the problems of safety management at construction sites were derived, and a direction for improvement proposed.

\subsection{Analysis of construction disaster cases}

In this study, the major factors of gang-form related disasters were analyzed, and gang-form work types and related materials frequently associated with disasters were drawn. Of 125 fatal accidents that occurred in the construction field from 2004 to 2011, 37 cases were related with gang-form[21]. More specifically, there was one case of a fall of attached material, 11 cases of falling accidents of the worker, 3 cases of rollover or crash of gang-form, and 22 cases of fall and death during work caused by gang-form collapse or drop during the process of gang-form lifting and demolition work. It was analyzed that in gang-form work, $74 \%$ of disasters occurred in lifting and demolition and $20 \%$ of disasters occurred in installation work, and that by composition part, about $86 \%$ of disasters took place in cages and work scaffolding(Figure 2).

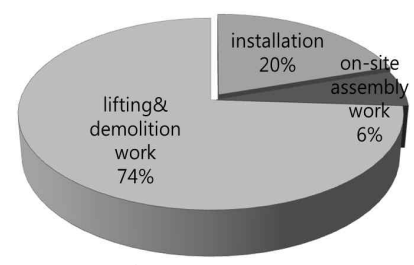

(a) Work steps

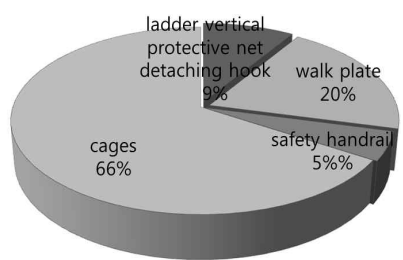

(b) Composition
Figure 2. Case analysis result of severe disasters with gang-form

In the lifting and demolition work, construction disasters occurred frequently and repeatedly because the bolts that conjoined concrete wall and gang-form were disconnected without binding the gang-form with lifting equipment including a tower crane, and the gangform collapsed as a result. 94\% of construction disaster cases related with gang-form were found in installation work, and lifting and demolition work, and Table 2 indicates the safety factors of the fatal accidents.

\subsection{Analysis of public and private safety guidelines}

The problems with the safety guidelines utilized at construction sites are analyzed by identifying the key factors of construction safety accidents based on the case studies of construction disasters. Safety guidelines published by Korea Occupational Safety and Health Agency (KOSHA) and by major General contractors companies in Korea were analyzed (Table 3).

Table 2. Safety factors of gang-form works

\begin{tabular}{|c|c|}
\hline Works & Items \\
\hline $\begin{array}{l}\text { On-site } \\
\text { assembly } \\
\text { and } \\
\text { installation }\end{array}$ & $\begin{array}{l}\text { - Use of damaged auxiliary rope for lifting } \\
\text { - Omission of vertical protective nets } \\
\text { - Omission of safety handrail } \\
\text { - Rollover of walk-plate } \\
\text { - Omission of safety belts } \\
\text { - Non-extension of walk-plates } \\
\text { - Omission of inspection for damage caused by } \\
\text { external force } \\
\text { - Non-application of anchor bolts when concrete pouring }\end{array}$ \\
\hline $\begin{array}{l}\text { Lifting \& } \\
\text { demolition } \\
\text { work }\end{array}$ & $\begin{array}{l}\text { - Collision between gang-forms } \\
\text { - Hook withdrawal of chain block } \\
\text {-Poor supporting of lifting equipment } \\
\text { - Use of partially disassembled lifting equipment } \\
\text { - Omission of inspection for damage caused by } \\
\text { external force } \\
\text { - Non-application of anchor bolts when concrete pouring }\end{array}$ \\
\hline
\end{tabular}

Table 3. Safety guidelines for gang-form works

\begin{tabular}{cl}
\hline Type & \multicolumn{1}{c}{ Safety related documents } \\
\hline \multirow{2}{*}{ KOSHA } & $\begin{array}{l}\text {-Safety work guideline for gang-form works (2000) } \\
\text {-Safety guideline for production/use of gang-form }\end{array}$ \\
& -6'th improvement plan for standardization of gang- \\
& form works (2004) \\
& -Special safety instruction for gang-form works (2005) \\
Construction & - Standard model of risk management (2009) \\
and & -Safety at gang-form works (2008) \\
engineering & -Standards for production/use of gang-form (2003) \\
company & -Standards for production/use of gang-form (2006) \\
& -Safety guideline for gang-form works (2008) \\
& -Standard guideline for safety work with gang-form \\
& (2009) \\
\hline
\end{tabular}

Safety guideline for gang-form work by KOSHA (2000) comprehensively describes a safety related information about gang-forms, including general information (i.e. product performance), production, installation, lifting and assembly and disassembly. It provides a safety checklist consisting of up to 13 items by safety criteria, composition part including safety railing and work type(Table 4). 'A guideline for gang-form production and safety for users (2011)' provides a simple description on the standard dimensions 
Table 4. Safety checklist for gang-form works

\begin{tabular}{|c|c|}
\hline Works & Safety check items \\
\hline $\begin{array}{l}\text { On-site } \\
\text { assembly } \\
\quad \text { and } \\
\text { installation }\end{array}$ & $\begin{array}{l}\text { - Installation status of safety handrails for fall prevention } \\
\text { at the end of walk plates } \\
\text { - Installation status of toe board for prevent falling } \\
\text { objects } \\
\text { - Installation status of straight ladder } \\
\text { - Interval of less than } 200 \mathrm{~mm} \text { of between walk plates }\end{array}$ \\
\hline $\begin{array}{l}\text { Lifting \& } \\
\text { demolition } \\
\text { work }\end{array}$ & $\begin{array}{l}\text { - Planning status for lifting \& demolition works } \\
\text { - Dismantling of the anchor bolt before derricks or } \\
\text { tower crane hold a lifting hook } \\
\text { - Designate a safety manager } \\
\vdots\end{array}$ \\
\hline
\end{tabular}

of composition parts and work safety when using a gang-form. The safety criteria presented by KOSHA are insufficient in terms of objectivity and apparentness, and the factors of construction disasters that repeatedly occur every year are not reflected in the guideline.

Safety guidelines for gang-form work presented by General contractors were identified to derive common factors, and the reflection of the causes of disasters in the guidelines and applicability to the sites was analyzed. The safety guidelines from six General contractors ranked within the top 10 as of 2010 were analyzed. Of the safety criteria using by General contractors, the common items by composition part of gang-form are summarized in Table 5.

Table 5. Safety inspection items in gang-form works

\begin{tabular}{|c|c|}
\hline $\begin{array}{c}\text { Material } \\
\text { composition }\end{array}$ & Common Items \\
\hline $\begin{array}{l}\text { Walk- } \\
\text { plate }\end{array}$ & $\begin{array}{l}\text { - More than } 40 \mathrm{~cm} \text { width, } 60 \mathrm{~cm} \text { or more width at lowermost } \\
\text { - Fastening with } U \text { bolts when fixed } \\
\text { - Installation of safety handrails at the end of plates } \\
\text { - Frequent check for damages caused by external force }\end{array}$ \\
\hline $\begin{array}{l}\text { Corner- } \\
\text { plate }\end{array}$ & $\begin{array}{l}\text { - Mounting of brackets under walk-plates of the corner } \\
\text { - Lower than } 20 \mathrm{~cm} \text { gap between plates }\end{array}$ \\
\hline $\begin{array}{l}\text { Safety } \\
\text { ladder }\end{array}$ & $\begin{array}{l}\text { - Alternate arrangement between upper and lower } \\
\text {-Less than } 30 \mathrm{~cm} \text { step interval of steps }\end{array}$ \\
\hline Cage & $\begin{array}{l}\text { - Installation of walk-plates meticulously at the bottom } \\
\text { to prevent a falling accident } \\
\text { - Frequent check for the fixed state of end of safety handrail } \\
\text { - Color display for fixing anchor after installation } \\
\text { - Prevention of dismantling the anchor bolts before the } \\
\text { unity of the tower crane }\end{array}$ \\
\hline $\begin{array}{l}\text { Vertical } \\
\text { protective } \\
\text { net }\end{array}$ & $\begin{array}{l}\text { - Meticulous installation of nets in the entire cage } \\
\text {-Application of anti-flaming materials } \\
\text {-Higher than } 150 \mathrm{kgf} \text { tensile strength }\end{array}$ \\
\hline $\begin{array}{l}\text { Lifting } \\
\text { hook }\end{array}$ & $\begin{array}{l}\text {-Application of bolt fastening method using a sheet of } \\
\text { iron } \\
\text {-Assembly with sufficient consideration of the safety factor } \\
\text { - Frequent check for the omission of bolts and welding }\end{array}$ \\
\hline
\end{tabular}

The criteria applied regardless of gang-form part include rust prevention and painting state of parts, fire extinguisher installation, whether oxygen welding equipment is used or not, use of a safety belt during installation work, and discontinuation of work under winds of $10 \mathrm{~m} / \mathrm{sec}$ or higher. For the safety railing, there are no common criteria for safety management, and only a few General contractors stipulate criteria for installation height and load. The safety guidelines published by General contractors consisted of more diverse items than those published by KOSHA, and preventive safety criteria for repeated disasters are reflected by composition part or work type. However, the inspection period and body are not clearly specified, resulting in low applicability on construction sites.

\subsection{Questionnaire survey}

We investigated the current state of the on-site use of aforementioned safety guidelines for the gang-form and gang-form related construction disasters through a questionnaire survey. 100 subjects are selected as a pool of workers, subcontractors managers, general contractors managers, and safety manager who had more than 3 years of work experience in gang-form work. The questionnaires are composed of three parts: questions about the frequency and severity of disasters, utilization and problems of the conventional safety guidelines, and improvement directions, and a total of 72 questionnaires were collected(Table 6).

Table 6. Composition of respondents

\begin{tabular}{cccccc}
\hline Work & Position & $\begin{array}{c}\text { Sub- } \\
\text { experience }\end{array}$ & $\begin{array}{c}\text { General } \\
\text { Workerstractor } \\
\text { manager } \\
\text { mantractor } \\
\text { manager }\end{array}$ & $\begin{array}{c}\text { Safety } \\
\text { manager }\end{array}$ & Total \\
\hline $3-6$ years & 3 & 4 & 2 & 3 & \\
$6-9$ years & 2 & 4 & 5 & 4 & \\
$9-12$ years & 7 & 2 & 3 & 3 & 72 \\
$12-15$ years & 4 & 5 & 4 & 2 & \\
More than 15 years & 5 & 3 & 2 & 5 & \\
Number & 21 & 18 & 16 & 17 & \\
\hline
\end{tabular}

In the questions on the frequency and the severity of gang-form related construction disasters, $42 \%$ and $72 \%$ of the respondents described frequency and severity as "high" or "very high." The gang-form related safety accidents occurred substantially at con- 
struction sites, and the potential for fatal accidents is high[Figure 3 (a),(b)]. In the questions related with the use of the conventional public and private safety guidelines, $71 \%$ of the respondents replied that some or none of the guidelines are utilized, and the reasons for avoiding the use of guidelines include the high number of items, the complexity of guidelines, and the inclusion of items that did not reflect site conditions[Figure 3(c),(d)].

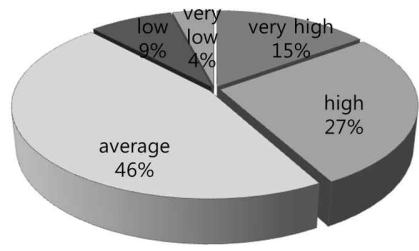

(a) Disaster frequency

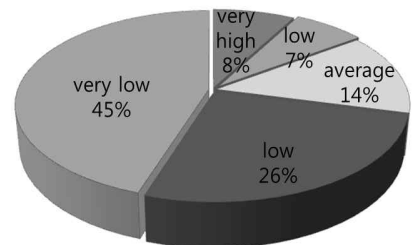

(c) Frequency of using guideline

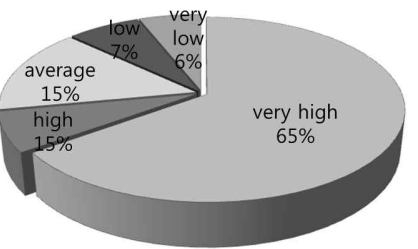

(b) Level of disaster risk

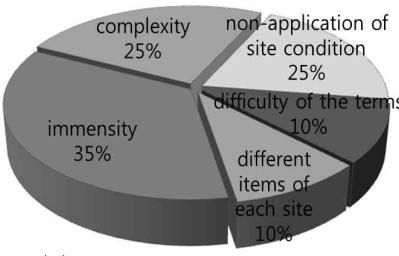

(d) Factors of disliking the existing guidelines
Figure 3. Current state of construction disaster occurrence and the use of safety guidelines in gang-form work

Through the questionnaire analysis, it was found that gang-form work has a high rate of fatal accident occurrence, and appropriate measures for safety management should be prepared. However, the complexity and the inappropriateness of the conventional guidelines for the various site conditions resulted in low utilization by site practitioners. In addition, according to the results of 'companies awareness of workplace safety,' the perception level of workers regarding safety was described to be 2.21 out of 5 on average, which implies that the perception level of construction workers regarding safety was very low[7]. The cause of the frequent occurrence of construction disasters at a specific gang-form work stage is identified as the unsuccessful implementation of safety management, not only due to the absence of safety guidelines but also due to insufficient worker awareness of safety.

\subsection{Problems of safety management of gang-form work, and direction for improvement}

We identified the diverse problems of safety management in gang-form work through the analysis of disaster cases and the interviews with professionals. First, although similar types of disaster have occurred in specific work types repeatedly, there are no specific alternatives to these in the existing public safety guidelines. Second, despite the development and application of safety guidelines by General contractors, they are rarely utilized due to the following limitations: (1) the content is different for each company, (2) there are too many items to check, and (3) guidelines are too complicated to use. Third, the safety management body is not clearly specified because of multiple steps of cooperation between different stakeholders due to the contractual structure of the construction industry, which interferes with active and preventive safety management.

First, a standardized inspection tool, systematically composed, that is appropriate for the characteristics of a construction site should be used, respecting safety management dependent on knowledge and experience. By developing standard checking tables, the inspection items that are repeated or omitted can be complemented. Second, establish the on-site safety management scheme that can be cross checked by multiple participants. Management activities are differentially assigned to each participant to minimize the inspection items omitted and maximize the management efficiency.

\section{Development of hierarchical checking table}

\section{$\mathrm{s}$ for safety management}

\subsection{Hierarchical checking scheme for safety management}

Under the Industrial Safety and Health Law, the safety and health management system for construction sites consists of diverse management agents including safety managers, management supervisors. In this study, a hierarchical checking scheme was presented for agents including safety managers, management supervisors of subcontractor and general contractor, and workers who perform safety management activities at 
construction sites. Each participant generates a four-level hierarchical linkage structure among the agents, and fulfills the classified roles of safety management activities such as checking or confirming safety factors in ongoing projects. Workers not only complete inspection of basic safety management items by work type but also sequential activities. Management supervisors inspect whether the activities performed by workers are finished precisely and control them. Safety managers guide and advise management supervisors on related technical items, and check omitted inspection.

Based on identify the safety management activities of apartment gang-form work by checking participants from Level 1(workers) to Level 4(safety managers), we present the hierarchical checking scheme for safety management. The safety management items are inspected by the participant in charge with the advancement of construction. The items inspected by levels of priority are checked by upper-level participants. For instance, the safety management item GC inspected by workers will be checked again by the Safety manager(Figure 4).

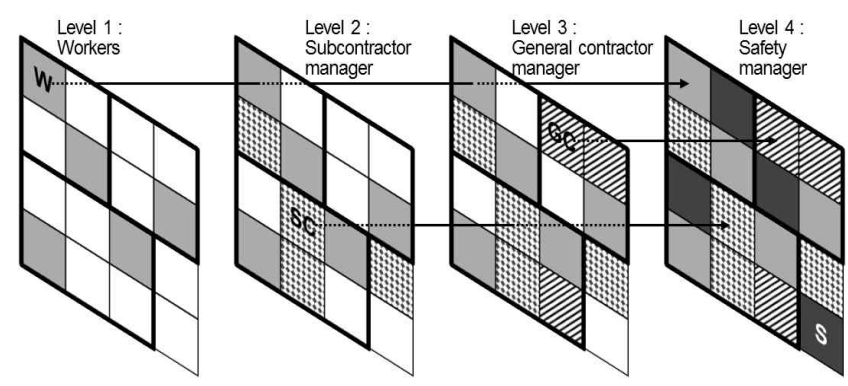

Figure 4. Hierarchical checking scheme

\subsection{The hierarchical checking tables for safety management by participant}

The hierarchical checking tables for safety management by participant was proposed based on survey responses to the 137 safety inspection items derived through an analysis of public and private safety guidelines for gang- form work. A total of 65 practioner with more than 6 years of experience as a worker, a subcontractor manager, a general contractor manager were selected from the survey pool. The questionnaire survey was conducted from April 1 to April 17, 2011 by visiting 10 construction sites. We asked the respondents to check one or more items which must be inspected or checked by participants for 137 inspection items(Table 7).

The participant who was checked the most in the questionnaire results was selected as the checking participants. The safety inspection items were composed of 38 items for workers, 34 items for subcontractor's managers, 35 items for general contractor's managers, and 30 items for safety managers.

To support expeditious safety management activities by levels of priority without omission, the hierarchical checking tables were proposed based on the subdivided and enumerated safety inspection items by gang-form composition part and work type in Table 8. Considering the field conditions, the hierarchical checking tables can be utilized in diverse ways. Before construction, it can make safety stakeholders aware of the critical safety factors in gang-form work. After construction, safety management activities can be performed without redundancy by presenting appropriate safety inspection or check items for each safety stakeholder. In addition

Table 7. Survey result of safety inspection items

\begin{tabular}{|c|c|c|c|c|c|c|}
\hline \multirow{2}{*}{$\begin{array}{c}\text { Material } \\
\text { composition }\end{array}$} & \multirow{2}{*}{ Works } & \multirow{2}{*}{ Safety check items } & \multicolumn{4}{|c|}{ Number of respondents } \\
\hline & & & W & SC & GC & $s$ \\
\hline & & (1) $40 \mathrm{~cm}$ or wider & 3 & 7 & 12 & 44 \\
\hline Walk-plate & On-site assembly & $\begin{array}{l}\text { (2) Installation of a two-stage walk-plate at the upper and lower } \\
\text { portions, respectively } \\
\vdots\end{array}$ & 6 & 6 & 55 & 2 \\
\hline Common safety & Lifting \& demolition & (138) Assignment of a work execution manager and flagman & 5 & 10 & 51 & 2 \\
\hline precautions & work & (13) Omission of personal safety equipment & 38 & 15 & 10 & 9 \\
\hline
\end{tabular}

W: Workers, SC: Subcontractor manager, GC: General contractor manager, s: Safety manager 
Table 8. Hierarchical checking tables for safety management of apartment gang-form works

\begin{tabular}{|c|c|c|c|c|c|}
\hline Materials & & On-site assembly & & Installation & Lifting \& demolition work \\
\hline $\begin{array}{l}\text { Walk- } \\
\text { plate }\end{array}$ & $\begin{array}{l}\text { S } \\
\text { GC } \\
\text { GW } \\
\text { GC } \\
\text { SC } \\
\text { SC }\end{array}$ & $\begin{array}{l}\text { more than } 40 \mathrm{~cm} \text { width } \\
\text { Install two-stage walk-plate at the upper } \\
\text { and lower portions, respectively } \\
\text { install safety handrails at the end of } \\
\text { plates } \\
\text { use galvanized plate with holes at lowest } \\
\text { part } \\
\text { Install the storage box to prevent falling } \\
\text { accidents } \\
\text { check deformation, damage, and slack } \\
\vdots\end{array}$ & $\begin{array}{l}\text { W } \\
\text { SC } \\
\text { SC }\end{array}$ & $\begin{array}{l}\text { check frequently a horizontality } \\
\text { maintain the same height as the } \\
\text { cage } \\
\text { fastened with } U \text { bolts when fixed } \\
\text { within } 20 \mathrm{~cm} \text { distance between the } \\
\text { work- plate and the cage } \\
\text { install safety handrails at the end of } \\
\text { plates }\end{array}$ & $\begin{array}{l}\text { S check connection between bolts and } \\
\text { work-plates } \\
\text { GC check the fixed status of cantilever type } \\
\text { W remove falling objects before } \\
\text { disassemble forms } \\
\text { WI remove the protruding objects/oils induce } \\
\text { slip and fall } \\
\text { GC maintain the same height as the cage } \\
\text { SC check frequently a horizontality } \\
\text { SC check frequently for damages caused by } \\
\text { external force }\end{array}$ \\
\hline $\begin{array}{c}\text { Comer- } \\
\text { plate }\end{array}$ & & $\begin{array}{l}\text { extend plates to be in close with } \\
\text { adjacent corner-plate } \\
\text { lower than } 20 \mathrm{~cm} \text { gap between plates }\end{array}$ & W & $\begin{array}{l}\text { extend plates to be in close with } \\
\text { adjacent corner-plate at the ends of } \\
\text { outside corner of side wall } \\
\text { mount corner-brackets to prevent } \\
\text { deflection }\end{array}$ & $\begin{array}{l}\text { W. lower than } 20 \mathrm{~cm} \text { gap between plates at } \\
\text { the corner } \\
\text { SC check frequently ommission of } \\
\text { turnbuckle- nuts which adjust the corner } \\
\text { of the cage }\end{array}$ \\
\hline Ladder & & $\begin{array}{l}\text { install in order to be able to safely move } \\
\text { up/down } \\
\text { lower than } 30 \mathrm{~cm} \text { interval of steps } \\
\vdots\end{array}$ & Sc & $\begin{array}{l}\text { install on the side of building } \\
\text { arrange alternately between upper } \\
\text { and lower }\end{array}$ & $\begin{array}{l}\text { move back the walk-plates to the } \\
\text { original position whenever the workers } \\
\text { moved }\end{array}$ \\
\hline & w & & & & \\
\hline $\begin{array}{l}\text { Safety } \\
\text { handrail }\end{array}$ & $\begin{array}{l}\text { SC } \\
S\end{array}$ & $\begin{array}{l}\text { overlapping part of safety handrail } \\
\text { install the upper cages at outside } \\
90-120 \mathrm{~cm} \text { height of the upper safety } \\
\text { handrail \& } 45-60 \mathrm{~cm} \text { height of the middle } \\
\text { safety handrail }\end{array}$ & GC & $\begin{array}{l}\text { the top of the forms } \\
\text { structure to withstand the weight of } \\
100 \mathrm{~kg}\end{array}$ & $\begin{array}{l}\text { of safety handrail } \\
\text { sc check frequently for the omission of } \\
\text { fixing hardwares }\end{array}$ \\
\hline $\begin{array}{l}\text { Common } \\
\text { safety } \\
\text { precautions }\end{array}$ & $\begin{array}{l}\text { WC } \\
\text { SC } \\
\frac{5}{S C}\end{array}$ & $\begin{array}{l}\text { ommission of personal safety } \\
\text { equipments } \\
\text { have a prior consultation with workers } \\
\text { about the work procedure and time } \\
\text { application of oxygen welding } \\
\text { check the anti-rust coating of materials } \\
\text { prepare fire extinguisher }\end{array}$ & $\frac{\text { sc }}{\text { SC }}$ & $\begin{array}{l}\text { assign a work execution manager } \\
\text { and a flagman } \\
\text { employs experienced craftsmen } \\
\text { application of safety belts } \\
\text { have a prior consultation with } \\
\text { workers about the work procedure } \\
\text { and time } \\
\text { assign management supervisor } \\
\text { prohibit the use of oxygen welding on } \\
\text { site }\end{array}$ & $\begin{array}{l}\mathrm{GC} \text { have a prior consultation with workers } \\
\text { about the work procedure and time } \\
\mathrm{GC} \text { coordinate the Work procedure } \\
\mathrm{S} \text { establish the communication system } \\
\text { between tower crane operator/flagman, } \\
\text { worker who disassemble bolts, ground } \\
\text { flagman } \\
\mathrm{GC} \text { assign a work execution manager and flagman } \\
\mathrm{SC} \text { operates a professional work team } \\
\mathrm{W} \text { ommission of personal safety } \\
\text { equipments }\end{array}$ \\
\hline
\end{tabular}

W: : Workers, Sc : Subcontractor manager, GC: General contractor manager, s : Safety manager

the practical applicability can be improved since hierarchical checking tables can be reorganized by work type and composition part of gang-form work.

\subsection{Applicability evaluation}

To evaluate the practical applicability and to get opinions on the improvements, interviews with practitioners were conducted on May 8, 14, and 21 through on-site visits. From the pool of questionnaire respondents, 20 experts with more than 9 years of experience from 5 construction fields where gang- form is currently applied were selected. The evaluation criteria are composed of three categories: (1) the appropriateness of inspection items, (2) the usefulness at construction sites, and (3) possibility of accident prevention. Each criterion is analyzed using a 5-point scale (very low, low, moderate, high, very high), and opinions on improvement ideas were converged. The analysis results are indicated in Table 9. 80\% and 70\% of respondents answered 'high' or 'very high' regarding the appropriateness of inspection items by work type and composition part of gang-form work and the effectiveness of accident prevention of the hierarchical checking tables for safety management, respectively. 60\% of respondents responded 'high' or 'very high,' which is relatively low. In terms of major improvements and additions, advance provision of qual- 
ity safety education, safety and utilization of risk evaluation linked as part of the health management system were presented.

Table 9. Result of analysis of interview

\begin{tabular}{lccccc}
\hline \multicolumn{1}{c}{ Evaluation Item } & $\begin{array}{c}\text { Very } \\
\text { good }\end{array}$ & Good & $\begin{array}{c}\text { Not } \\
\text { bad }\end{array}$ & Bad & $\begin{array}{c}\text { Very } \\
\text { Bad }\end{array}$ \\
\hline $\begin{array}{l}\text { 1. Item applicability by } \\
\text { level }\end{array}$ & $\begin{array}{c}1 \\
(5 \%)\end{array}$ & $\begin{array}{c}15 \\
(75 \%)\end{array}$ & $\begin{array}{c}3 \\
(15 \%)\end{array}$ & $\begin{array}{c}1 \\
(5 \%)\end{array}$ & - \\
2. Item applicability by & - & 16 & 4 & & \\
component & & $(80 \%)$ & $(20 \%)$ & - & - \\
3. Effectiveness in field & - & 12 & 6 & 2 & - \\
$\begin{array}{l}\text { 4. Effectiveness in } \\
\text { accident prevention }\end{array}$ & - & 14 & 5 & 1 & - \\
\hline
\end{tabular}

\section{Conclusion}

This study proposed systematic checking tables for safety management that can support hierarchical safety management activities for participants by reflecting the practical applicability of gang-form work.

Based on analyses of fatal accident cases in gangform work, public and private safety guidelines, and interviews with practitioners, several problems were identified: a lack of measures to prevent repeated construction disasters, a lack of site applicability of safety guideline of general contractors, and vagueness of the safety management system.

To develop hierarchical checking tables for safety management that can support mutual inspection or checking by safety stakeholders considering site conditions, the following procedure was used. The hierarchical checking scheme for safety management was developed consisting of 4 levels by participant in gang-form work. A questionnaire survey was conducted on 65 practitioners with 6 years of work experience or more, and management items by participant level composed of 38, 72, 107, and 137 items were identified. The hierarchical checking tables were proposed through reorganizing the inspection items by work type or composition part of gang-form work.

To validate the practical applicability of the checking tables, we assessed the evaluation criteria, which included the appropriateness of inspection items by construction stage or checking participants, the usefulness of the checklist at construction sites, and the possibility of fatal accidents prevention using a 5-point scale through interviews with practitioners. It was found that the hierarchical checking tables can support a successful safety management by dividing the inspection items considering the levels of priority of checking participants.

For general application and enhancement the safety inspection items for gang-form, a larger number of construction sites should be analyzed. Further studies should be conducted to secure the on-site efficiency of safety management items by considering the inspection process for each participant and to establish the apposite application plan that can be theoretically reorganized by participant, work type, and composition part.

\section{References}

1. Loe JH, Yang SH, Kim YS. Development of an automated gangfor m climbing system for apartment housing construction: structur al stability and tower crane lifting load analysis. Korean Journal of Construction Engineering and Management. 2012 Jul;13(4):4 8-59.

2. Huang RY, Sun KS, Chen JJ. Construction planning for gang formwork reuse using simulation. Proceedings of the 17th Intern ational Symposium on Automation and Robotics in Construction; 2000 Sep 18-20;Taipei, Taiwan. Taipei (Taiwan): The Internatio nal Association for Automation and Robotics in Construction; 2000. p. 1153-61.

3. Shin HW, Kim GH, Kim JY, Cho HK, A research on a comparison between the strength and weakness of each formwork methods in the core wall construction. Journal of the Korea Institute of Building Construction. 2007 Dec; 7(4):153-9.

4. Peurifoy RL, Oberlender GD. Formwork for concrete structures. 4th ed. New York: McGraw-Hill; 2011. 518 p.

5. Kim GH, Kang KI. A study on development and application of the unit table form for concrete structural frame work of high-rise buildings. Journal of the Architectural Institute of Korea. 2003 Aug;19(8):181-8.

6. Choudhry RM, Fang DP, Ahmed SM. Safety management in construction: best practices in Hong Kong. Journal of Profession 
al Issues in Engineering Education \& Practice. 2008 Jan;134(1):2 $0-32$.

7. Loe HC, Yeo SK, Go SS. A study on the improving safety managem ent by analyzing safety consciousness of construction labors. Journal of the Korea Institute of Building Construction. 2009 Jun;9(3):51-8.

8. Ahn HS. A study on the improvement of the safety organizations for construction projects. Journal of the Architectural Institute of Korea. 2005 Sep;21(9):137-44

9. Abdelhamid TS, Everett JG. Identifying root causes of constructi on accidents. Journal of Construction Engineering and Manage ment. 2000 Jan;126(1):52-60.

10. An, SH, Ryu HW, Park MS. Selecting key accident risk factors in building construction projects. Journal Of the Korea Institute of Building Construction. 2011 Feb;11(1): 45-50.

11. Son CB, Kim BL. Improvement of the field management work and operation system in the apartment construction. Journal of the Architectural Institute of Korea. 2006 Jun; 22(6):165-72.

12. Fang DP, Huang XY, Hinze J. Benchmarking studies on constructi on safety management in China. Journal of Construction Enginee ring and Management. 2004 Jun;130(3): 424-32.

13. Yi KJ. Proactive safety planning model by integrating hazard risk and work schedule. Journal of the Architectural Institute of Korea. 2004 Apr;20(4):109-16.

14. Løe HS, Løe KP, Park MS, Baek YJ, Lee SH, RFID-based real-tim e locating system for construction safety management. Journal of Computing in Civil Engineering. 2012 May;26(3): 366-77.

15. Jia N, Xie M, Chai X. Development and implementation of a GIS-based safety monitoring system for hydropower station construction. Journal of Computing in Civil Engineering. 2012 Jan;26(1):44-53.

16. Hallowell MR, Gambatese JA. Activity-based safety risk quantifi cation for concrete formwork construction. Journal of Constructi on Engineering and Management. 2009 Oct; 135(10):990-8.

17. Moon S, Choi B, Yang B. USN-based data acquisition for increasi ng safety in the concrete formwork operation. Journal of Computi ng in Civil Engineering. 2012 May;26(3):271-81.

18. Yang YC, Choi H, Kim JJ. A study of methods on safety checklist improvement and integrated operation with schedule for constru ction accident prevention. Korean Journal of Construction Engin eering and Management. 2004 Apr;5(2): 123-35.

19. Shim UJ, Suh HS, Ahn YS. Highly efficient checklist for the safety management of reinforced concrete construction. Journal of the Korea Institute of Building Construction. 2010 Dec;10(6):7 -17 .
20. Kim JR, Yoon SY, Cho YJ. Hands-on tools to prevent human errors in highway construction. Journal of the Ergonomics Societ y of Korea. 2011 Feb;30(1):19-28

21. Lee KT. Analysis of causes and the precautionary measures on disaster caused by the collapse of the gang form. Incheon (Korea): the Occupational Safety and Health Research Institute; 2005 Dec. Report No.: 2005-82-544. 31 p. 